\section{THE IAKE FOREST HOSPITAL FOR CONTAGIOUS DISEASES}

\section{ALIRED C. HAVISN, M.D.}

J.AKE FOREST, ILL.

The treatment of contagious diseases in private homes is very unsatisfactory. Every community should provide a hospital for such eases. What are the requirements of an ideal isolation hospital?

'The location ought to be secluder, and the gromils spactions, allowing comvaleseents ont-door exercise. 'The huilding should be planned for the purpose, and not "lirty" room, and after disinfecting, removed from the boiler into the "clemn" room, or the "dirty" room alone may be used for the formaldehyd proess. A laumily and a store-room should also be provided in the basement. I'le floors in the warls should be of cement with no angles or corners, to collect dust, and there should be hose comnections in cach joom for clemnsing.

'The caretaker should oceupy a separate cottage to the rear of the hospital. This should contain not only a living-room, chambers and bath, but also a good-sized kitchen where the meals for the entire linepital may be prepared and carried to the wards on simple wooden

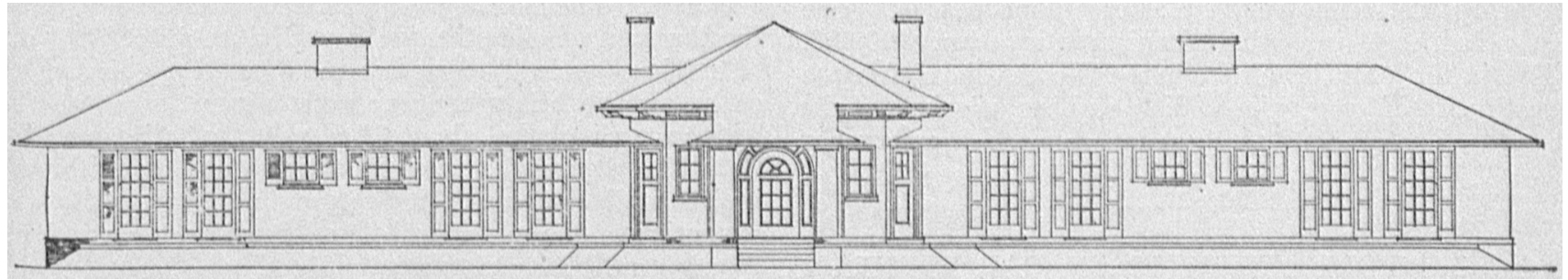

Flg. 1.- Front elevation of the Lake liorest lsolation Hospltal.

remodeled. It should have, preferably, an east frontage, securing sunshine morning and afternoon. The building should be one story in height and fire-proof. It should be adapted for isolating not only the two sexes, but also. for separating several different diseases simultaneously, and keeping them so. The physicians should have rooms for

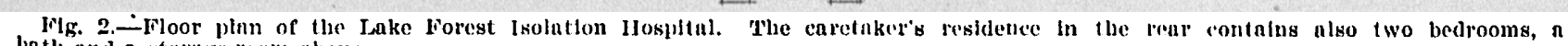

exchanging clothes prior to visits, and facilities for bathing afterward. JRooms inust be provided for office, 'aboratory, dispensury and supplies. Groups of wards, or private rooms, in units, viz.. a ward with six beds, a dict kitchen, with gas range and sink, a bathroom, preferably with slower baths and movable iron tubs, and, if possible, a small nurses' private room should be included in the plams. These units may be multiplied to meet the demand. The bascment should contain two disinfecting rooms, the "dirty" and the "clean" rooms. In the partition ividing them should be placed the steam boiler for clisinferting purposes. All goods to be treated are brouglit, in suitable sealed bags, to the occupied by patients. The entire hospital should be surrouncled by a coment terrnce ten feet wide. The warls are entered from the terrace on the outside.

Suppose the hospital is in active use. The pluysician enters the main hall and the physician's room, puts on his duck suit and rubbers, passes out on the terrace and enters the ward or wards he wishes to visit. He returns by terrace to the plyysician's room, has his shower bath, dons his former clothes, and passes ont. The patient is brought in the ambulance, which lacks up to the terrace door of the lesired ward.

The grounds about the hospital should be attractively laid out, and planted with shrubs. The terms "con- 
tagious" or "pest house" should be replaced by more euphonious terms.

These are the ideals that have inspired the trustees and arehitect, Mr. Charles S. Frost, in planning an jsolation hospital for Iake Forest, as slown in the accompanying plans. It will be noted that the end wards in each wing have no connecting nurses' retiring rooms. T'his arrangement was made in order to save space. These wards are intended for female patients and the nurse in each will oceupy one of the beds in the ward. 'The terraces are not covered by porches in order that as much sunshine as possible may reach the warts. 'The grounds cover three acres. 'The exterior of the building will. be of rough plaster on metal lath. The estimated cost, including furniture, is about $\$ 20,000$. This is the only hospital on the North Shore for the treatment of contagious disenses exclusively. Lake Forest also has a liospital, Alice Ilome, for emergency cases.

\section{ACUTIS POLIOMY AHITIS IN CALIFORNIA}

\section{F. F. GUNJIRUM, M.1.}

SACRAMENTO, CAL.

Acute poliomyelitis lias been existent in California for a good many years, appearing sporadically, and in occasional epidemies. 'The disease hes not until recently been considered contagious and the public health reports are, therefore, extremely unsatisfactory sources from which to obtain data concerning the history of this malarly in the state.

I'lue first case of which I lave been able to get an accurate account occurred in Sureka, California, in 1875. The case was a typienl one, in a child, aged 2 years, with acute onset followed in a fow lays with paralysis in the lower extremities. This putient tells me that another child had the same disease at "nbout the same time." A search through the California journols on file in the state library, and through the Index Medicus, las failed to give me any further enses recorded between 1875 and 1896 . In $189 \%$ appeared a report by Sherman ${ }^{2}$ of eight cases occurring in the state during the summer of 1896: of these, seven were in San Francisco, and one in Napn. Newmark" reports four cases occurring in Mereed County in the summer of: 1898. Woods" describes an epidemic, "about fifty cases," occurring in and about San Francisco in 1901, with a recurrence of "several cases" in 1902. Since 1902, no literature of the disease in California has appeared that we could find.

During the summer of 1910 , however, the most extensive epidemic yet seen in this state prosented itaelf. Under the auspices of the state hourd of health I had an opportunity to obtain all the available records and to see a considerable number of these cases. The San Francisco Medical Society appointed a commission to investignte the epidemic as it prevailed in that city. $\Lambda$ copy of this excellent report has been sent to the board by Dr. Ji. C. Fleischner," chairman of the committee, and has been incorpornted into the rata of the epidemic of 1910 in the state. On account of the fact that in the beginning the disense was not a reportable one to the board, a good many cases are doulstless unecorded. It has been some time since we have had many cases of this

1. Shermun, 11. M. : Oceld. Med. 'T'mes, Auguat, 1807, p. 445.

2. Newmark, Jeo: Med. News, is90, Ixxlv, 101.

3. Woods, A, M.: Occtd. Med, Jimes, March, 15ios, p. 77.

4. Flelschner, B. C.: Cal. State Jour. Med., September, 1011. discase, and a diagnosis may have been occasionally overlooked, especially in abortive or l'apidly fatal cases. It is certain, therefore, that our reports are incomplete and the deductions drawn from then must, of course, be more or less faulty. The epidemic of 1910 did not differ in clinical features from the characteristics of the ordinary type of the disease. We were able to collect a complete record of 125 cases; 120 in 1910, and five before October, 1911. Of these cases, 75 per cent. occurred from May to September, 1910. The number of males attacked was practically (louble that of the females; 63 to 37 per cent. Seventy-three per cent. of the eases were under 8 years. The onset in 88 per cent. was given as sudden, and in $\mathbf{1 2}$ per cent. slow. 'The type of onset for the sake of classification was divided into:

1. The classical, or gastro-intestinnl type, in which gastro-enteric disturlances, with fever, predominate. This group included about 6 it per cent. of all eases.

2. The meningitic type, in which symptoms of meningeal irritation were most prominent, such as the retraction of the neck, etc. This group comprised about 25) per cent. of the conses.

3. 'The abortive, which practically does not appear in this investigation as it was thought impossible, in tho

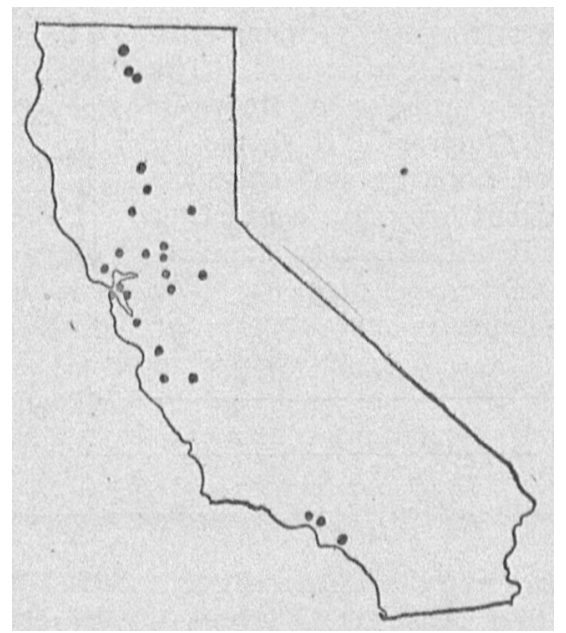

Map of Californla showing geographienl distribution of acuto polfomyelitis from Junuar, 1910, to October, 1911. Dots indicate focalitios from whleh cases of the disense were rejported.

alsence of facilities for doing any serodiagnostic work, to draw definite conclusions from so inclefinite a symptom-complex. No anses were included in the report unless paralysis oecurred. Of the paralysis, 23 per cent. occurred in the upper, $\% 3$ per cent. in the lower extremities, the remaining 4 per eont. being enses in which trunk and respiratory muscles were involved causing deatl. 'There are seven deaths recorded, making a mortality rate of 6 per cent. in the epidemic. It is very probable that this death-rate is too low. Biglity-two per cent. of the cases logan with fever; 54 per cent. with gastro-intestinal ilisturbance; 46 per cent. without marked gastro-intestinal symptoms.

Since the work of Flexner," who has shown that poliomyelitis is a transmissible disease, we lave been particularly anxious to trace, if possible, the mode of transmission in order to work out some practical sanitary method for the limitation of the infection. In the ficid, however, it his been unbelievably difficult to demonstrate dircet transmission. In the 125 cases I was able to elicit a listory of exposure in eleven only, or 9 per cent.; in

5. Flexner, Simon: 'The Jounnal A. M. A., Sept. 24, 1010, p. 1108 . 